\title{
Exploring Two Types of Aggressive Behavioural Risk Factors among Illegal Motorcycle Street Racers in Malaysia
}

\author{
Zalmizy Hussin ${ }^{1, *}$ and Siti Rohana Ahmad ${ }^{2}$ \\ ${ }^{1}$ Universiti Utara Malaysia, Sintok, Kedah, Malaysia \\ ${ }^{2}$ Kedah State Health Office, Ministry of Health Malaysia
}

\begin{abstract}
Illegal motorcycle street racing is a threat to civil society - it is a symbol of adolescents' inner rebellion who channelled their unfulfilled desire through aggressive behaviour on the road, causing significant social and economic impact. Aggressive behaviours have been associated with prohibited substances intake, lack of religious knowledge, problematic family structures, and school failure. In this qualitative study, abductive strategies oriented to phenomenological approaches were employed to assess two types of aggressive behaviour risk factors, which were substance abuse and problematic family structures. In-depth interviews were conducted with thirty people in Penang, Malaysia, who participated in illegal street racing, referred to as Mat Rempits. Their responses were analysed using the NVivo software version 12. The results demonstrate three subthemes to prohibited substances intake: to relieve stress, for personal enjoyment, and for racing purposes, whereby the drugs are taken before races for the riders to be more courageous, aggressive, and agile manoeuvring the motorcycles. Meanwhile, the risk factor of family problems includes divorced and conflicted parents, raised by violence, being neglected, and not being appreciated by the family. Most of the participants stated that growing up with violence caused a psychological impact on their soul, making them stubborn, rude, and aggressive. The results demonstrate the need for a specific intervention programme for the adolescent to reduce their involvement in illegal street racing and aggressive behaviour.
\end{abstract}

Keywords: Risk factors, aggressive behaviour, substances abuse, problematic family structures, a street racer.

\section{INTRODUCTION}

Illegal motorcycle street racing is a threat to a civil society with significant social and economic impact (Vingilis \& Smart, 2009). An illegal motorcycle race is a motorised race conducted on public roads without permission from the authorities and is often held in urban, rural, or industrial areas regardless of traffic conditions at midnight. Such racing activities are illegal as the races endanger both the lives of other road users and the riders. There is a strong motorcycle racing culture that involves Malaysian youth, known as "Mat Rempit" in the Malay Language. If arrested, they will be investigated under Section 42, Road Transport Act 1987. According to Hussin (2017), Mat Rempit is a person who engages with street gangs that drive motorcycles precariously, risking themselves and other road users, in addition to committing violent crimes. Most of them perform dangerous riding stunts such as the Supermen style, the zig-zag style, and the head bowing. The authorities note that some of the offences committed by these groups include not having a driver's licence and the absence of side mirrors and backlights on the riders' motorcycles. Apart from that, the motorcycle tends to be modified with noisy exhaust and small tyres with the registration number removed. Illegal racing and convoyed activities typically occur

*Address correspondence to this author at the Universiti Utara Malaysia, Sintok, Kedah, Malaysia; E-Mail: zalmizy@uum.edu.my spontaneously, uncontrollably, and randomly organised with minimal security regulations and measures (Peak, K. J., \& Glensor, 2004; Warn et al., 2004; Wong, 2011). Furthermore, some groups will also organise and coordinate illegal racing. Participating or organising such races sparked a sense of pride in them as some of them consider themselves as heroes for displaying various dangerous stunts to the public.

Illegal racing has been described as a domestic approach for an individual to rebel against parents, the public, and the authorities (Ismail, R. \& Burhanuddin, 2009; Leigh, 1996). It is also an activity that involves risky and aggressive driving (Vaaranen \& Wieloch, 2002) that causes the perpetrator to violate social norms and values, and traffic regulations (D. Parker et al., 2000). Edwards (2001) noted that youths on motorcycles often perform dangerous actions on the road and act violently to the extent of harassing other road users, in addition to reckless driving and risky illegal behaviours such as snatching money, displaying aggressive behaviour, and frequently engaging with spontaneous activities (Bina et al., 2006; Falconer \& Kingham, 2007; Ismail, R. \& Burhanuddin, 2009; Vaaranen, 2004; Vaaranen \& Wieloch, 2002). They also obstruct the traffic as they tend to gather at road intersections and perform various risky stunts that put them and others at risk (Ibrahim et al., 2015). Apart from that, it has been noted that some vehicle owners use it to release their agitation, anger, and aggression. 
Despite their renowned negative consequences and long existence, there is a lack of empirical research on illegal motorcycle street racers (Vingilis \& Smart, 2009). On the other hand, there are numerous conceptual frameworks on the risk factors of aggressive behaviour among youth. Some of the risk factors of aggressive behaviours are intake of prohibited substances, lack of religious knowledge, and problematic family structures. Regarding the intake of prohibited substances, Siegel, and McCormick (2006) note that there is a relationship between the level of drug abuse and violence. Meanwhile, youths with positive guidance from their families and high religious awareness have been observed to be able to withstand a negative environment (Syarifah et al., 2010). Several studies claim that the structure and socioeconomic status of a family influence youth risk factors aggressive behaviours (DeLisi et al., 2020; Falk et al., 2017; Farrington, 2013; Kierkus \& Hewitt, 2009; Ward et al., 2010) as it has been observed that low household socioeconomic status - measured by family income is associated to adolescent substance use (Kun et al., 2019; Marceau et al., 2020; Pei et al., 2020). In addition, a problematic family structure such as marital disruption has also been associated with cognitive, emotional, and behavioural problems (Hay et al., 2006; Raine et al., 2005; White et al., 2001).

Risk factors can increase one's probability of acting aggressively and engaging in other social problem activities (Turbin et al., 2006). The increased aggressive verbal and physical behaviour among Mat Rempits, when exposed to risks, is seen as a huge threat that leads towards criminal misconduct and may shape an aggressive and violent personality. In a social environment, they tend to use relatively harsh and rude language, in addition to engaging in physical violence. The lack of attention on the risk factors prompts criminal misconduct activities by the Mat Rempits without any control from the authorities, such as motorcycles and cars theft for spare parts, vandalism, drug abuse, burglary, grazing, rape (Ibrahim et al., 2015), gangsterism, assault, fights, and bullying (Wan Shahrazad et al., 2012), which placed considerable risk on injury and death (Sá et al., 2017; Tavakoli Kashani et al., 2014).

Following these observations, the risk factors influencing their aggressive behaviour should be further studied as risk factors such as the intake of a prohibited substance and problematic family life hinder the continued development of youth human capital for nation-building.

\section{LITERATURE REVIEW}

\section{Substances Abuse}

Substances abuse has been associated as a risk factor for an individual to engage in criminal behaviour (Armstrong et al., 2005; Ashton \& Bussu, 2020; Case \& Haines, 2007; Papalia et al., 2018) and the possibility of repeatedly committing a crime (Duke et al., 2017; Parker \& Auerhahn, 1998). Hawkins et al., (1992) note that the use of the prohibited substance has been associated with crime and aggressive behaviour among youth as young as 12 years old.

Substance abuse is a major public health concern due to the negative effects and frequency of its use by youths (Rohde et al., 2001) as substance abuse and addiction occur at high rates. Apart from that, there has been an observable association between parents who use illegal substances and aggressive behaviour among youths. A study of 1,252 respondents in Minnesota demonstrates that youths who consume alcohol and youths with drug-dependent parents are about two to three times more likely to have externalising disorders compared to their counterparts (Marmorstein et al., 2009). Such genetic and environmental factors, such as being raised by drugdependent fathers, can potentially influence the risk of a youth's involvement in aggressive crime (Haber et al., 2010).

\section{Problematic Family Structure}

An unstable family institution is a determinant of aggressive behaviour problems among youths, which is preventable through harmonious and carefully guarded family institutions with parents who understand the will of the young generation and are prepared to help them to face future challenges. Ryan et al., (2010) and Ward et al., (2010) observe that a detachment between parents and children also referred to as family disorder, can prompt the children's involvement in aggressive and criminal behaviour. Their studies are echoed earlier by (Calhoun et al., 1993), who note that those from a broken family or a single-mother family tend to be involved in aggressive behaviour compared to their peers.

Aggressive behaviour is related to the structure of a family, as demonstrated by Kierkus and Hewitt (2009) comparison study between teenagers living in nontraditional homes (fathers, single parents with stepfathers, single parents with other siblings) and those who live in traditional households (with both 
biological parents). The study demonstrates that living in a non-traditional household increases the probability of aggressive behaviour, based on variables such as socioeconomic status, family size, and age. Along the same line, Loeber et al., (2008) note that those abandoned by their parents before the age of 10 have a higher tendency to demonstrate aggressive attitudes and behaviour up to the age of 32 , regardless of family income or primary school achievement. Apart from that, family conflicts are also a risk factor for family problems related to youth. Exposure to parental conflict can cause youths to be aggressive and to engage in delinquent behaviours (Derzon, 2010), and such conflicts can also cause other risk factors such as family income, physical punishment from the parent, and criminal parents (Fergusson et al., 2000)

Moreover, poor family management practices such as poor monitoring, inconsistent rules, harsh discipline (Herrenkohl et al., 2000), unclear family law, and lack of parental supervision (Herrenkohl et al., 2007) are associated with aggressive behaviour in children and adolescences and instigated criminal behaviour in adulthood (Fagan et al., 2007). As noted by Hoeve et al., (2009) and Derzon (2010), poor family management can be a high-impact risk factor pertaining to aggressive behaviours.

\section{RESEARCH METHODS}

This qualitative study employed abductive research strategies that were oriented towards phenomenological approaches to gather authentic findings from the perspectives of Mat Rempits. The information shared by Mat Rempits based on their experience pertaining to aggressive behavioural activities were the core of the study, which was later interpreted to further understand their social reality. The study was conducted in the Penang state where comprises the highest number of illegal motorcycle racers in Malaysia. Many streets, roads, highway in Penang have become sites for racing. Jalan Tun $\mathrm{Dr}$ Awang, Jalan Mahsuri, Jalan Bukit Gambir, Jalan Sungai Dua, and Lebuhraya Gelugor were identified as routes that were often used by Mat Rempits to participate in mass gathering and disrupt the public peace. Participants were recruited through a snowball sampling and were selected based on the following criteria: a) teenagers or youths of Mat Rempits, b) between the age of 16 and 29, c) had experienced illegal racing activities, d) certified true by their friends e) ready and volunteered to share their life experience as Mat Rempits.
The selected participants were interviewed and were later asked to introduce us to other members of his group. In short, the sample in this study was constructed based on the reference provided by the initial informants. Personal information on participant's sociodemographic (age, occupation, education, type of residence, living with) and engagement in racing activities (driving licence, ownership of motorcycle and brand, summoned by police, experience the police custody, ever had an accident, age and period of involvement) were collected using proforma developed purposed for this study. Their information was kept confidential as this study involved high-risk respondents that were labelled negatively by society. Each participant was interviewed for 45 minutes to onehour using an interview guided questionnaire consisted of risk factors and aggressive behaviour. The interviews were recorded using a recorder and the recordings were later transcribed using the Microsoft Office Word software and computed into the NVivo software for coding purposes. This recruitment and interview process were carried out and reached its saturation points with 30 participants.

The coding process involved identifying quotes in text and storing references to specific quotes in a database item called node (in NVivo software), which contained various references and able to encode quotes from any documents provided. When the data saturation was reached, unimportant and inconsistent categories and sub-categories were removed, and the coding process for the next document was halted. When the coding process was performed on all available data, the data were stored in several different categories in the node (either free node, tree node or case node). At this stage, relevant themes or concepts were unearthed and re-encoded to define the category better. Afterwards, statements significant to the phenomenon were extracted from the transcript and analysed to separate the data from the context of the informant's original case from coded data segments to mark each segment in the data text (Starks \& Trinidad, 2007). Significant data texts were coded, and the codes were derived from the meaning embedded in the informants' narrative text combined with the researcher's words, a process referred to as open coding. In this study, thematic analysis was used as it was the most flexible data analysis method (Braun et al., 2019). The thematic analysis involved identifying patterns or themes in important or meaningful qualitative data to explain the issues being studied. Braun et al. (2019) steps in performing thematic 
analysis were employed. At first, the data was evaluated before creating a start-up code to establish the theme. The theme was later reviewed, defined, and explained in detail through writing.

\section{RESEARCH FINDINGS AND ANALYSIS}

A total of 30 illegal racers were included in this study. The socio-demographic characteristics of the participants and their engagement in illegal racing activities are shown in Tables 1 and 2 . The mean age of study participants was $22.0 \pm 3.14$ years (range, 17 28). All of them are males, Malay, Malaysian and single. The majority of them worked as mechanics, factory workers, and food conveyors and possessed a degree or diploma. Meanwhile, most of them lived in terrace houses and with their families. Apart from that, most of them had a valid driving licence and self-owned their motorcycle. The mean age of first involvement in illegal racing was 19 years old. One third of participants have a history of summoned by police, had experience the police custody, and also had an accident.

The Mat Rempits began their illegal racing activities usually around $11.30 \mathrm{pm}$ until $3.00 \mathrm{am}$ on weekends and public holiday nights such as New Year's Eve and other festivals. The informants also admitted that they tend to participate in illegal racings in urban areas compared to rural areas that were typically carried out on a straight road in selected locations. Such races were often designed by the organisers at a specific place and time. Apart from that, it was observed that the Mat Rempits often used small power motorcycles, between 100cc to $125 \mathrm{cc}$, such as Yamaha 125Z, Yamaha RXZ, Honda EX5, Modenas, and Suzuki RGV motorcycles. They also modified the engine parts such as the carburettor, cam, head, exhaust, clutch, and gearbox. As stated by R5:

"Modification of this motor is usually done on certain types of motorcycles and most motorcycles are modified four-stroke type motorcycles because the cost is cheaper and not complicated to modify".

He added:

"Many non-essential motor components are left before modifying one motor. First, modify the motor frame first to lower it closer to the ground to be stable and reduce wind direction resistance," (while inviting researchers to drink).
At the same time, the R5 also talked about the modifications of the engine parts. R5 stated:

"After finishing that just now ... modifications will be done on the engine parts such as carburettor, cam, head, exhaust, clutch, and gearbox".

Researchers also inquired about the source of the spare parts components. $\mathrm{R} 5$ responded by stating:

"Usually can get special components for illegal racing that can be found at motorcycle spare parts shops ...".

According to R5:

"When it is ready to be modified, a jockey who has experience will test first ...want to test and see if there is anything that can be repaired at the last minute before being handed over to his master".

He added:

"Ready to modify, the motor will be taken to a straight circuit in several secret locations" (Laughing).

R5 also said:

"This illegal race is usually only between motor workshop owners and rarely involves individuals. We bet money and never bet on women and drugs. We are not like the new boy who rides like crazy and endangers the safety of other road users. We only choose the right straight road at selected locations around Penang and racing usually involves only two motorcycles at a given time. (It only lasted) ... in a short period only ... selected audience only. We also went outside the Penang area to race... My friend was arrested and went to jail. I am very lucky to have never been arrested...".

Apart from that, R12 shared that he and his crew members failed to avoid police roadblocks. When he was stopped by the police, the latter asked for his licence and road tax. He failed to do so and was summoned as he had no licence and his road tax had expired. He and his crew felt provoked and tried to fight the police, causing him to almost be detained and 
locked up. Consequently, he and some of his friends spent the rest of the night in police lock-up.

Furthermore, some of the informants also shared their accident experiences. Informant R19 recounted his road accident while participating in illegal racing activities with his friends on weekend nights, stating that those who had never been in an accident was deemed weak and not macho. The statement made by R19 demonstrated that Mat Rempit was fearless and would continue to ride while they were young and remained interested in the world of motoring.

Table 1: Demographic Characteristic of Illegal Motorcycle Racers (Mat Rempits) $(n=30)$

\begin{tabular}{|c|c|}
\hline Variables & Frequency $(\%)$ \\
\hline Age mean $\pm S D$ (years) & $22(3.14)$ \\
\hline \multicolumn{2}{|l|}{ Occupation } \\
\hline Students & $8(26.7)$ \\
\hline Unemployment & $5(16.7)$ \\
\hline Mechanic & $7(23.3)$ \\
\hline Factory workers & $6(20.0)$ \\
\hline Food conveyor & $4(13.3)$ \\
\hline \multicolumn{2}{|l|}{ Education level } \\
\hline MCE (Secondary schools Form 5) & $12(40.0)$ \\
\hline Diploma & $16(53.3)$ \\
\hline Degree & $2(6.7)$ \\
\hline \multicolumn{2}{|l|}{ Type of residence } \\
\hline Rented house & $4(13.3)$ \\
\hline Terrace house & $9(30.0)$ \\
\hline Apartment house & $11(36.7)$ \\
\hline Village house & $6(20.0)$ \\
\hline \multicolumn{2}{|l|}{ Living with } \\
\hline Friends & $9(42.8)$ \\
\hline Family & $21(57.2)$ \\
\hline
\end{tabular}

*Malaysian Certificate of Education.

For risk factor analysis, an interpretation theme was extracted. Based on the interpretation theme, two subthemes were constructed, as shown in Table 3.

\section{Subtheme a: Intake of Prohibited Substances}

In this study, three reasons for the intake of prohibited substances were discovered - for racing purposes, to relieve stress, and for personal enjoyment. Those who took drugs for illegal races tend to engage in aggressive behaviour, as noted by R4,
$\mathrm{R} 7$, and R10. According to them, the drugs were meant to make them more courageous, aggressive, and agile during the race. As noted by R4:

Table 2: Engagement in Illegal Racing Activities of Mat Rempits $(n=30)$

\begin{tabular}{|c|c|}
\hline Variables & Frequency (\%) \\
\hline \multicolumn{2}{|l|}{ Driving licence status } \\
\hline Yes & $18(60.0)$ \\
\hline No & $12(40.0)$ \\
\hline \multicolumn{2}{|l|}{ Ownership of motorcycle } \\
\hline Borrow & $13(43.3)$ \\
\hline Self-Owned & $17(56.7)$ \\
\hline \multicolumn{2}{|l|}{ Motorcycle brand } \\
\hline Honda Japan & $13(43.3)$ \\
\hline Yamaha Japan & $10(33.3)$ \\
\hline Modenas Malaysia & $5(16.6)$ \\
\hline Suzuki Japan & $2(6.8)$ \\
\hline \multicolumn{2}{|l|}{ Summoned by police } \\
\hline Yes & $12(40.0)$ \\
\hline No & $18(60.0)$ \\
\hline \multicolumn{2}{|l|}{ Experience police custody } \\
\hline Yes & $11(36.6)$ \\
\hline No & $19(63.4)$ \\
\hline \multicolumn{2}{|l|}{ Ever had an accident } \\
\hline Yes & $8(26.6)$ \\
\hline No & $22(73.4)$ \\
\hline Age of first involvement & $19.83(2.15)$ \\
\hline \multicolumn{2}{|l|}{ Period of involvement } \\
\hline Less than 2 years & 20 \\
\hline More than 2 years & 10 \\
\hline
\end{tabular}

Table 3: Themes and Subthemes Extracted from Analysis of Risk Factors

\begin{tabular}{|c|c|}
\hline \multirow{1}{*}{$\begin{array}{c}\text { Theme } \\
\begin{array}{c}\text { Risk factors of } \\
\text { aggressive behaviour } \\
\text { among Mat Rempits }\end{array}\end{array}$} & $\begin{array}{c}\text { Subtheme a } \\
\text { Intake of Prohibited Substances } \\
\text { 1. Taking drugs for racing purposes. } \\
\text { 2. Consuming drugs to relieve stress. } \\
\text { 3. Using drugs for fun. }\end{array}$ \\
\cline { 2 - 2 } & $\begin{array}{c}\text { Problematic family structures } \\
\text { 1. Violence-based teachings. } \\
\text { 2. Children are not appreciated by } \\
\text { parents. }\end{array}$ \\
& $\begin{array}{c}\text { 3. Life is spent and taken care of. } \\
\text { 4. Conflict between mother and father. } \\
\text { 5. Divorced and fragmented families. }\end{array}$ \\
\hline
\end{tabular}


"I take drugs to race ... If there is no drug in me, I will be scared and not feel confident to race ... So, I feel happy ... The drug makes me strong and dares when you want to start racing. By taking drugs, I feel brave and not afraid when accelerating at high speeds while doing illegal racing activities".

Meanwhile, R7 stated that:

"I have been addicted to drugs for a long time ... It is just that I rarely get amicable because I do not have money to buy. That is why when there is an illegal race ... I will get the goods. If I win... the money I use a little to buy drugs. The drug I bought will make me happy when I want to race. But sometimes I also like that thing to relieve the pressure in me".

The excerpts demonstrated that the informants consumed drugs to participate in an illegal race, and the money won in such races tend to be used to buy drugs.

Meanwhile, R10 stated that he took Kratom (Mitragyna speciose) while racing, which was referred to as ketum in the Malay Language. He claimed to feel stronger and better when he drank ketum water:

"Every time there is a race ... I prefer to drink ketum water. This ketum water is easy to buy and easy to get... the price is low. If you buy drugs it is difficult to get new supply stock. right now, I only drink ketum water if there is a race".

This shows that ketum water was consumed as it was cheaper than drugs and easier to access from the black market. In addition to taking drugs for racing purposes, drugs were also used to provide peace of mind and relieve stress. This notion was also demonstrated by other respondents, such as R15 who stated:

"I am addicted to this drug, it only relieves stress... when taking drugs, the brain becomes delusional and does not think anything. I feel depressed when I am at home. My mom and dad are just fighting... Moreover, when I take that thing, my brain calms down".
The informant noted that he was addicted to drugs as the substance allowed him to escape from his stressful life. The family turmoil experienced by R15, for example, prompted him to take drugs to relieve his emotional problems.

It was also observed that drugs were consumed for their pleasure, as noted by R20:

"I took the drug just for fun ... I took the drug to feel calm and fun. I was addicted to drugs due to pressure from friends. My friend told me that drugs can give more focus to race... So, I tried it ... it is normal ... drowsiness can disappear ... illegal racing activities are sometimes done late at night ... When I take the drug, the body feels strong ... I feel like I get angry easily and sometimes I become violent ...".

From the R20 statement, drugs caused the users to have less emotional control and to encourage their engagement in violent behaviour. It was noted that R20 used syabu, a type of drug, to increase his focus at night, but the substance was more harmful to him due to severe addiction.

Table 4: Frequency and Percentages of Use of Prohibited Substance by Mat Rempits

\begin{tabular}{|c|c|c|}
\hline Types of Prohibited Substances & Frequency & $\begin{array}{c}\text { Percentage } \\
\text { (\%) }\end{array}$ \\
\hline \hline Kratom & 13 & 43.0 \\
Alcohol & 8 & 27.0 \\
Drug (Methamphetamine) & 6 & 20.0 \\
Ecstasy & 3 & 10.0 \\
\hline Total & 30 & 100 \\
\hline
\end{tabular}

Table 4 presents the frequency and percentage of types of illicit substances taken by Mat Rempits. It was observed that 13 respondents (43 per cent) used Kratom, eight respondents (27 per cent) consume alcohol, 6 respondents ( 20 per cent) used drugs, and 3 respondents (10 per cent) took ecstasy pills.

Some informants displayed uncomfortable expressions related to this topic. Informant R11 stated:

"I feel this question is too sensitive for me to answer... and please do not ask this question," (as if the informant is not comfortable with the question asked). 
Informant R14 displayed a similar attitude:

"Emm... I do not want him to answer this question... is there another question?"

Due to the sensitivity of the question, R18 was nervous to answer this question and requested complete anonymity to answer the question as he was worried if his information was relayed to the police and he would be arrested for using drugs. The informant was assured of his confidentiality based on the research ethics employed in this study. Informant R18 stated:

"I did take that thing... now I am addicted. If you have that thing ... my soul is rebellious, and my mind is fibrous".

When asked about the source of the banned material, R18 stated:

"Emm... it is a secret and I cannot tell in this interview session. If I tell you later, the secret will be leaked, and the police may find and arrest me ... So, I think I do not need to answer that question".

The informant's stance was respected, and the interview session continued.

\section{Subtheme b: Problematic Family Structures}

As shared by R21, his parents' violent approach to educate him caused a psychological impact on his soul to become aggressive, stubborn, rude, and disrespectful to his parents. The anger was released through aggressive behaviour. It was observed that abusive parents influence the informant's aggressiveness. As stated by R21:

"My parents are fierce ... they want to hit me a little. My tension ... That is why ... I like to swear at people if they do not hit my wind ... I like my mother's words ... I admit I am stubborn ... um ... there is I will also talk rudely to my mother if my mother is angry with me ...".

Meanwhile, R8 stated that he felt unappreciated by his parents and felt that his parents were not supportive concerning his daily lessons and activities.

"I feel I am not appreciated by my parents. Even in my studies, they never took notice ... that is why the situation in my house made me feel fibrous and bored ... I better go out and hang out with friends".

Informant R27 echoed this attitude:

"I did evil even my parents did not know and did not care (while laughing)".

Apart from that, R22 also felt neglected and ignored by his parents as the latter were busy working and did not spend much time monitoring their children at home.

"Emm ... I think in my life no one cares about my parents is busy with their work ... My parents never cared about me and what I did outside. ... So, I better go out to meet my friends and it is good to share the problem".

"I think my friends understand me better than my parents. I am free to do anything ... my family does not care about me either. So, I am free to go home or not go back to sleep at home. When together with friends you can laugh ... chats ... pornographic and rude chats".

Apart from that, R16 seemed to become an aggressive person due to the unpleasant atmosphere in his family as his parents often quarrelled, causing him to leave the house for amusement that were mainly aggressive. He stated that:

"I am tired of my parents just fighting ... it can be said that every week there are two to three fights ... I feel very depressed when I am at home ... Other people have a happy family ... But I do not ... (sad tone). My parents are busy fighting in front of me ... snoring and angry ... eh ... I cannot tell the story ... I think I should go out looking for the best things like speeding motorcycles and getting involved in racing illegal to release my problem ... hit the traffic light and all that'.

Meanwhile, an informant stated that he acted aggressively because his parents were divorced, and the absence of a father figure influenced his aggressive behaviour as he was unhappy living with his mother. He felt unhappy with his life. Informant R30 stated that:

"I became aggressive because I felt myself not having fun in life. Moreover, my 
family is not like other happy people. And ... I admit too ... I never prayed. My parents never taught me and told me to pray".

\section{DISCUSSION}

Some criminologists view illegal motorcycle racing gangs as a type of juvenile delinquency because they violate the rules and laws of the road, while some noted that illegal racing among youths is a temporary activity Leigh (1996, p. 388-393). This study demonstrates that the majority of Mat Rempits admit that their aggressive behaviour is influenced by the consumption of prohibited substances, which are taken for races, relieving stress, and for personal pleasure. Drugs are taken before the races to increase the rider's courage to drive the motorcycle at high speed and increase his agility to control the motorcycle. In addition, some informants consume drugs to relieve their stress with their family situation, which includes repeated arguments between their parents. There is also a unique and scientifically unproven finding in this study; the informants use drugs to stay awake late at night to participate in illegal racing activities and to feel tougher, but the drugs make them aggressive and unable to control themselves. The findings are in line with previous studies which demonstrate that the consumption of illicit substances such as drugs, ketum, and ecstasy is associated with the risk factors of an individual engaging in aggressive or criminal behaviour (Armstrong et al., 2005; Case \& Haines, 2007; Roe \& Becker, 2005) and with increased crime rates (Putninš̌, 2003). Meanwhile, Nazar (2004) have shown that a lack of religious education and problematic family factors are highly associated with drug-taking and abuse activities among youths.

Moreover, the results also demonstrate weak parental skills - a harsh parental approach has had a psychological effect on the informant's soul, prompting him to be aggressive. Violent parenting style causes children to be rebellious, stubborn, rude, and disrespectful to their parents. Most parents display their anger aggressively, causing their children to be aggressive as well due to abusive parenting. This observation is consistent with previous studies that noted that abusive nursing practices such as using force, inconsistent, or lack of discipline are risk factors for aggressive behaviour (Hawkins et al., 2012; Herrenkohl et al., 2000). Derzon (2010) echoed this notion, observing that types of discipline (consistent versus inconsistent discipline), disciplinary punishment methods, and frequency of beatings contributed to aggressive and violent behaviour.

Family influence is vital in shaping personalities, thoughts, and behaviours for positive upbringing; hence, the role of parents is very much emphasised in educating children. Caring parents will be aware of their children's activities will not allow misconduct. As caregivers, they need to be concerned about their children's behaviour and social activities such as their children's friends, locations, and activities. Concerned parents also tend to not allow night outings. This study demonstrates that an unstable family is unable to fulfil the emotional and spiritual needs of its members, especially the children. It should be noted that family conflict is related to youth problems and studies have shown that exposure to parental conflict is a risk factor for aggressive or criminal behaviour (Derzon, 2010; Loeber et al., 2008). Meanwhile, Haji Othman et al. (2016) argues that a failed family system can affect the personality formation and education of children, which will eventually affect their future as they tend to engage in a social system and not be able to become useful and visionary people.

It can be observed that an individual's attitude can shape his behaviour. As stated by (Hassan, 1998), attitudes are learned and acquired through social environment plays. Therefore, unhealthy thinking and lifestyle can lead to drug abuse. In this study, most of the respondents claim that they use drugs to reduce their stress and such an approach is related to the Lazarus and Folkman's (1984) by Biggs et al. (2017), which states that some individuals abuse drugs to avoid or reduce stress. In this situation, the users perceive that using drugs can reduce their stress without realising the consequent addiction as the stress will resume once the drugs lost their influence.

The snowball sampling techniques in this study made a significant contribution to unravel the phenomenon of aggressive behaviour among illegal motorcycle riders. The use of such an approach is supported by Wong (2011) and Ibrahim et al. (2015), who noted the suitability of the technique to evaluate the issue of Mat Rempits in Malaysia. Using this technique, several informants were initially identified and were asked to introduce the researcher to other informants, allowing the researcher to recruit relevant informants to complete the research. The researcher was introduced to the chief by two informants. Then, the snowball sampling techniques were used to recruit other informants with the help of their chairman. The 
researcher managed to recruit other participants who were willing to be interviewed on the recommendation of the previous informants. This snowball sampling technique was done in stages with in-depth interviews. This technique was efficient and effective while conducting the research. The sampling method successfully met the research criteria that was accurate, relevant, and reliable data validity.

\section{CONCLUSION}

This study successfully identifies the needs of youths and the important findings in the study are expected to draw attention to the existing voids that should be filled immediately. From the findings, the government can organise programmes such as "Halal Racing Programmes" for illegal motorcycle racers. Apart from that, future research should assess the protective factors - the characteristics of individual, family, community, or society to reduce or eliminate risks in the family and community - with regards to convoy activities and illegal racing and their involvement in violent crimes as such studies are lacking in Malaysia. The recommendations from such studies should be considered to solve the issue of violent crimes within the context of illegal racing.

The level of risk varies according to age, individual developmental level, individual personal characteristics, accessibility of environmental resources, and other factors that may have a negative impact in the future. Every individual is constantly exposed to risk factors but what differentiates one person from another is their quality and the existing environment that can act as a protective factor against a risk factor. The interviews in this study demonstrate the need to develop a specific intervention programme to help parents and adolescents reduce the risk factors of aggressive behaviour among illegal motorcycle racers. It is hoped that such programmes will consider the findings and ideas presented in this study.

\section{COMPLIANCE WITH ETHICAL STANDARDS}

All procedures performed in studies involving human respondents were in accordance with the ethical standards of the Research and Innovation Management Centre (RIMC), Universiti Utara Malaysia. The RIMC conducts an ethics review prior to the beginning of this research. Informed consent was obtained from all individual respondents included in the study.

\section{FUNDING}

The author(s) received financial support from Universiti Utara Malaysia (Colleges Grants: S/O code: 14825) for the research, authorship, and/or publication of this article.

\section{REFERENCES}

Armstrong, D., Hine, J., \& Hacking, S. (2005). Children, risk \& crime: The on track youth lifestyles surveys: Home Office Research Study. In Children, risk \& crime: The on track youth lifestyles surveys: Home Office Research Study (Issue January). http://search.ebscohost.com/login.aspx?direct=true\&db=cja\&

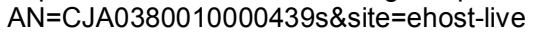

Ashton, S. A., \& Bussu, A. (2020). Peer groups, street gangs and organised crime in the narratives of adolescent male offenders. Journal of Criminal Psychology, 10(4), 277-292. https://doi.org/10.1108/JCP-06-2020-0020

Biggs, A., Brough, P., \& Drummond, S. (2017). Lazarus and Folkman's psychological stress and coping theory. In The Handbook of Stress and Health (pp. 349-364). https://doi.org/10.1002/9781118993811.ch21

Bina, M., Graziano, F., \& Bonino, S. (2006). Risky driving and lifestyles in adolescence. Accident Analysis and Prevention, 38(3), 472-481.

https://doi.org/10.1016/j.aap.2005.11.003

Blaikie, N. (2010). Designing social research: The logic of anticipation (2nd ed.). Cambridge: Polity.

Braun, V., Clarke, V., Hayfield, N., \& Terry, G. (2019). Thematic analysis. In Handbook of Research Methods in Health Social Sciences (pp. 843-860). https://doi.org/10.1007/978-981-10-5251-4_103

Calhoun, G., Jurgens, J., \& Chen, F. (1993). The neophyte female delinquent: a review of the literature. In Adolescence (Vol. 28, Issue 110, pp. 461-471).

Case, S., \& Haines, K. (2007). Offending by young people: A further risk factor analysis. Security Journal, 20(2), 96-110. https://doi.org/10.1057/palgrave.sj.8350031

DeLisi, M., Pechorro, P., Gonçalves, R. A., \& Maroco, J. (2020) Trauma, psychopathy, and antisocial outcomes among community youth: Distinguishing trauma events from trauma reactions. Youth Violence and Juvenile Justice. https://doi.org/10.1177/1541204020984214

Derzon, J. H. (2010). The correspondence of family features with problem, aggressive, criminal, and violent behavior: A metaanalysis. Journal of Experimental Criminology, 6(3), 263292. https://doi.org/10.1007/s11292-010-9098-0

Djamba, Y. K., \& Neuman, W. L. (2002). Social research methods: Qualitative and quantitative approaches. Teaching Sociology, $30(3), 380$. https://doi.org/10.2307/3211488

Duke, A. A., Smith, K. M. Z., Oberleitner, L. M. S., Westphal, A., \& McKee, S. A. (2017). Alcohol, drugs, and violence: A metameta-analysis. Psychology of Violence, 8(2), 238-249. https://doi.org/10.1037/vio0000106

Edwards, M. (2001). Standards for novice driver education and licensing. In driver education at the crossroads. Proceedings from the Committee on Operator Education and Regulation (Report No. E-C024), Transportation Research Circular. http://onlinepubs.trb.org/onlinepubs/circulars/ec024.pdf

Fagan, A. A., Van Horn, M. L., Hawkins, J. D., \& Arthur, M. W. (2007). Gender similarities and differences in the association between risk and protective factors and self-reported serious delinquency. Prevention Science, 8(2), 115-124. https://doi.org/10.1007/s11121-006-0062-1 
Falconer, R., \& Kingham, S. (2007). "Driving people crazy": A geography of boy racers in Christchurch, New Zealand. New Zealand Geographer, 63(3), 181-191. https://doi.org/10.1111/j.1745-7939.2007.00107.x

Falk, A. E., Lee, S. S., \& Chorpita, B. F. (2017). Differential association of youth attention-deficit/hyperactivity disorder and anxiety with delinquency and aggression. Journal of Clinical Child and Adolescent Psychology, 46(5), 653-660. https://doi.org/10.1080/15374416.2015.1055858

Farrington, D. P. (2013). Conduct disorder, aggression, and delinquency. In Handbook of Adolescent Psychology: Second Edition (pp. 627-664). https://doi.org/10.1002/9780471726746.ch20

Fergusson, D. M., Horwood, L. J., \& Nagin, D. S. (2000). Offending trajectories in a New Zealand birth cohort. Criminology, 38(2), 525-552. https://doi.org/10.1111/j.1745-9125.2000.tb00898.x

Haber, J. R., Bucholz, K. K., Jacob, T., Grant, J. D., Scherrer, J. F., Sartor, C. E., Duncan, A. E., \& Heath, A. (2010). Effect of paternal alcohol and drug dependence on offspring conduct disorder: Gene-environment interplay. Journal of Studies on Alcohol and Drugs, 71(5), 652-663. https://doi.org/10.15288/jsad.2010.71.652

Haji Othman, M. K., Mohd Yusoff, M. Z., Abdul Rahim, F., Puteh, A., Kasa, M. D., \& Roslan, N. (2016). Perspektif ibu bapa terhadap permasalahan dan cabaran dalam pembentukan nilai murni pelajar. Sains Humanika, 8(4-2). https://doi.org/10.11113/sh.v8n4-2.1052

Hassan, A. (1998). Masalah pelanggaran peraturan disiplin di sekolah. [Unpublished Master Thesis]. Universiti Putra Malaysia.

Hawkins, J. D., Catalano, R. F., \& Miller, J. Y. (1992). Risk and protective factors for alcohol and other drug problems in adolescence and early adulthood: Implications for substance abuse prevention. Psychological Bulletin, 112(1), 64-105. https://doi.org/10.1037/0033-2909.112.1.64

Hawkins, J. D., Herrenkohl, T., Farrington, D. P., Brewer, D., Catalano, R. F., \& Harachi, T. W. (2012). A review of predictors of youth violence. In Serious \& Violent Juvenile Offenders: Risk Factors and Successful Interventions (pp. 106-146). https://doi.org/10.4135/9781452243740.n7

Hay, C., Fortson, E. N., Hollist, D. R., Altheimer, I., \& Schaible, L. M. (2006). The impact of community disadvantage on the relationship between the family and juvenile crime. Journal of Research in Crime and Delinquency, 43(4). https://doi.org/10.1177/0022427806291262

Herrenkohl, T. I., Maguin, E., Hill, K. G., Hawkins, J. D., Abbott, R. D., \& Catalano, R. F. (2000). Developmental risk factors for youth violence. Journal of Adolescent Health, 26(7), 176186. https://doi.org/10.1016/s1054-139x(99)00065-8

Herrenkohl, T. I., McMorris, B. J., Catalano, R. F., Abbott, R. D., Hemphill, S. A., \& Toumbourou, J. W. (2007). Risk factors for violence and relational aggression in adolescence. Journal of Interpersonal Violence, 22(4), 386-405. https://doi.org/10.1177/0886260506296986

Hoeve, M., Dubas, J. S., Eichelsheim, V. I., Van Der Laan, P. H., Smeenk, W., \& Gerris, J. R. M. (2009). The relationship between parenting and delinquency: A meta-analysis. In Journal of Abnormal Child Psychology (Vol. 37, Issue 6). https://doi.org/10.1007/s10802-009-9310-8

Hussin, Z. (2017). Risk factors and forms of verbal and physical aggressiveness among mat motor and mat rempit in Penang, Malaysia. [Unpublished Doctorate Thesis]. Universiti Sains Malaysia.

Ibrahim, N., Ismail, R., Halim, M. R. T. A., \& Amit, N. (2015). Personality, high-risk activities and aggressive behaviour among illegal street racers. Mediterranean Journal of Social Sciences, 6(5S1), 527-533.

https://doi.org/10.5901/mjss.2015.v6n5s1p527

Ismail, R. \& Burhanuddin, B. (2009). Pendefinisian semula konsep rempit (Redefining the concept of 'Rempit'). Jurnal Psikologi Malaysia, 23(0), 11-17.

Kierkus, C. A., \& Hewitt, J. D. (2009). The contextual nature of the family structure/delinquency relationship. Journal of Criminal Justice, 37(2), 123-132. https://doi.org/10.1016/j.jcrimjus.2009.02.008

Kun, B., Urbán, R., Paksi, B., Griffiths, M. D., Richman, M. J., \& Demetrovics, Z. (2019). The effects of trait emotional intelligence on adolescent substance use: Findings from a Hungarian representative survey. Frontiers in Psychiatry, 10(JUN). https://doi.org/10.3389/fpsyt.2019.00367

Leigh, A. (1996). Youth and street racing. Current Issues in Criminal Justice, 7(3), 388-393. https://doi.org/10.1080/10345329.1996.12036716

Loeber, R., Farrington, D. P., Stouthamer-Loeber, M., \& White, H. R. (2008). Violence and serious theft: Development and prediction from childhood to adulthood. In Violence and Serious Theft: Development and Prediction from Childhood to Adulthood. https://doi.org/10.4324/9780203933237

Marceau, K., Brick, L. A., Knopik, V. S., \& Reijneveld, S. A. (2020). Developmental pathways from genetic, prenatal, parenting and emotional/behavioral risk to cortisol reactivity and adolescent substance use: A TRAILS Study. Journal of Youth and Adolescence, 49(1), 17-31. https://doi.org/10.1007/s10964-019-01142-8

Marmorstein, N. R., lacono, W. G., \& McGue, M. (2009). Alcohol and illicit drug dependence among parents: Associations with offspring externalizing disorders. Psychological Medicine, 39(1), 149-155. https://doi.org/10.1017/S0033291708003085

McNabb, D. E., \& McNabb, D. E. (2020). Introduction to qualitative research methods. In Research methods for political science (pp. 241-251). https://doi.org/10.4324/9781003103141-21

Merriam, S. (1998). Qualitative research and case study applications in education. Revised and expanded from"Case Study Research in Education". Jossey-Bass A Wiley Imprint, 1(1). http://www.eric.ed.gov/ERICWebPortal/recordDetail?accno= ED415771

Nazar, M. (2004). Gejala sosial di Malaysia masa kini: Antara puncanya. Seminar Pembangunan Insan Malaysia Di Akademi Pengajian Islam, Universiti Malaya.

Papalia, N., Luebbers, S., \& Ogloff, J. R. P. (2018). Child sexual abuse and the propensity to engage in criminal behaviour: $\mathrm{A}$ critical review and examination of moderating factors. In Aggression and Violent Behavior (Vol. 43, pp. 71-89). https://doi.org/10.1016/j.avb.2018.10.007

Parker, D., McDonald, L., Rabbitt, P., \& Sutcliffe, P. (2000). Elderly drivers and their accidents: The Aging Driver Questionnaire. Accident Analysis and Prevention, 32(6), 751-759. https://doi.org/10.1016/S0001-4575(99)00125-6

Parker, R. N., \& Auerhahn, K. (1998). Alcohol, drugs, and violence. Annual Review of Sociology, 24, 291-311. https://doi.org/10.1146/annurev.soc.24.1.291

Peak, K. J., \& Glensor, R. W. (2004). Street racing. Washington, D.C.: U.S. Department of Justice, Office of Community Oriented Policing Services.

Pei, F., Wang, Y., Wu, Q., Shockley McCarthy, K., \& Wu, S. (2020). The roles of neighborhood social cohesion, peer substance use, and adolescent depression in adolescent substance use. Children and Youth Services Review, 112. https://doi.org/10.1016/j.childyouth.2020.104931 
Putniņš, A. L. (2003). Substance use and the prediction of young offender recidivism. Drug and Alcohol Review, 22(4), 401408. https://doi.org/10.1080/09595230310001613912

Raine, A., Loeber, R., Stouthamer-Loeber, M., Moffitt, T. E., Caspi, A., \& Lynam, D. (2005). Neurocognitive impairments in boys on the life-course persistent antisocial path. Journal of Abnormal Psychology, 114(1), 38-49. https://doi.org/10.1037/0021-843X.114.1.38

Roe, S., \& Becker, J. (2005). Drug prevention with vulnerable young people: A review. Drugs: Education, Prevention and Policy, 12(2), 85-99. https://doi.org/10.1080/0968763042000322639

Rohde, P., Lewinsohn, P. M., Kahler, C. W., Seeley, J. R., \& Brown, R. A. (2001). Natural course of alcohol use disorders from adolescence to young adulthood. Journal of the American Academy of Child and Adolescent Psychiatry, 40(1), 83-90. https://doi.org/10.1097/00004583-200101000-00020

Ryan, J. P., Hong, J. S., Herz, D., \& Hernandez, P. M. (2010). Kinship foster care and the risk of juvenile delinquency. Children and Youth Services Review, 32(12), 1823-1830. https://doi.org/10.1016/j.childyouth.2010.08.003

Sá, T. H. de, Tainio, M., Goodman, A., Edwards, P., Haines, A., Gouveia, N., Monteiro, C., \& Woodcock, J. (2017). Health impact modelling of different travel patterns on physical activity, air pollution and road injuries for São Paulo, Brazil. Environment International, 108, 22-31. https://doi.org/10.1016/j.envint.2017.07.009

Siegel, L. J. \& McCormick, C. (2006). Criminology in Canada: Theories, patterns, and typologies (3rd ed.). Toronto: Thompson.

Starks, H., \& Trinidad, S. B. (2007). Choose your method: A comparison of phenomenology, discourse analysis, and grounded theory. Qualitative Health Research, 17(10), 13721380. https://doi.org/10.1177/1049732307307031

Syarifah, M. N., Turiman, S., Syamsilah, R., Rahil, M., Haslinda, A., Ismi Arif, I., \& Mursyid, A. (2010). Laporan kajian fenomena merempit dan potensi remaja lasak di FELDA. In Kementerian Pengajian Tinggi Malaysia.

Tavakoli Kashani, A., Rabieyan, R., \& Besharati, M. M. (2014). A data mining approach to investigate the factors influencing the crash severity of motorcycle pillion passengers. Journal of Safety Research, 51, 93-98. https://doi.org/10.1016/j.jsr.2014.09.004
Turbin, M. S., Jessor, R., Costa, F. M., Dong, Q., Zhang, H., \& Wang, C. (2006). Protective and risk factors in health-enhancing behavior among adolescents in China and the United States: Does social context matter? Health Psychology, 25(4), 445454. https://doi.org/10.1037/0278-6133.25.4.445

Vaaranen, H. (2004). The emotional experience of class: Interpreting working-class kids' street racing in Helsinki. Annals of the American Academy of Political and Social Science, 595, 91107. https://doi.org/10.1177/0002716204267494

Vaaranen, H., \& Wieloch, N. (2002). Car crashes and dead end careers: Leisure pursuits of the Finnish subculture of the kortteliralli street racing. Young, 10(1), 42-58. https://doi.org/10.1177/110330880201000104

Vingilis, E., \& Smart, R. G. (2009). Street racing: A neglected research area? Traffic Injury Prevention, 10(2), 148-156. https://doi.org/10.1080/15389580802641753

Wan Shahrazad, W. S., Fauziah, I., Asmah Bee, M. N., \& Ismail, B. (2012). A cooperative study of self-esteem, leadership and resilience amongst illegal motorbike racers and normal adolescents in Malaysia. Asian Social Science, 8(8), 61-68. https://doi.org/10.5539/ass.v8n8p61

Ward, A. K., Day, D. M., Bevc, I., Sun, Y., Rosenthal, J. S., \& Duchesne, T. (2010). Criminal trajectories and risk factors in a canadian sample of offenders. Criminal Justice and Behavior, 37(11), 1278-1300. https://doi.org/10.1177/0093854810379702

Warn, J. R., Tranter, P. J., \& Kingham, S. (2004). Fast and Furious 3: illegal street racing, sensation seeking and risky driving behaviours in New Zealand. 27th Australasian Transport Research Forum, October.

White, H. R., Bates, M. E., \& Buyske, S. (2001). Adolescence-limited versus persistent delinquency: Extending moffitt's hypothesis into adulthood. Journal of Abnormal Psychology, 110(4), 600-609. https://doi.org/10.1037/0021-843X.110.4.600

Wong, L. P. (2011). Socio-demographic and behavioural characteristics of illegal motorcycle street racers in Malaysia. BMC Public Health, 11. https://doi.org/10.1186/1471-2458-11-446

Received on 02-03-2021 Accepted on 09-04-2021 Published on 15-04-2021

https://doi.org/10.6000/1929-4409.2021.10.93

(C) 2021 Hussin and Ahmad; Licensee Lifescience Global.

This is an open access article licensed under the terms of the Creative Commons Attribution Non-Commercial License (http://creativecommons.org/licenses/by-nc/3.0/) which permits unrestricted, non-commercial use, distribution and reproduction in any medium, provided the work is properly cited. 